\title{
Soft tissue sarcomas in Mosul: a pathologic evaluation
}

\author{
Ahmad F. Lazim* Bedoor AK. Al-Irhayim** \\ Al-Jamhory Teaching Hospital-Mosul; **Department of pathology. College of Medicine, University of \\ Mosul.
}

(Ann. Coll. Med. Mosul 2008; 34(2):152-160).

Received: $13^{\text {th }}$ April 2008; Accepted: $15^{\text {th }}$ Oct 2008.

\begin{abstract}
Objective: Histochemical and immunohistochemical examination of soft tissue sarcomas(STS) in Mosul to assess the value of these techniques in verifying the primary diagnosis.

Methods: Paraffin embedded tissue blocks of 35 cases of soft tissue sarcomas collected over a period of 20 months in Mosul, were utilized. H\&E, reticulin ,and Van Gieson's staining techniques and immunohistochemical marker for S-100 protein were applied to all the cases.

Results: Soft tissue sarcoma accounts for $16.4 \%$ of the total of 213 cases of benign and malignant soft tissue neoplasms, with a mean age of 30.5 years, and a male preponderance( Male: Female ratio of 1.7:1). The most common histologic subtypes are extraskeletal Ewing's sarcoma(ES), dermatofibrosarcoma protuberans(DFSP), and spindle cell sarcoma, not other wise specified (NOS). The extremities are affected in $51.4 \%$ of all cases, particularly the lower limbs. The majority of soft tissue sarcomas belong to the high grade category by applying French Federation of Cancers Centers Sarcoma Group ( FFCCSG) and American Joint Cancer Committee (AJCC) grading schemes .Both reticulin and Van Gieson's stains have been successfully depicting the growth patterns of different subtypes. Immunoreactivity for S-100 protein was positive in two cases.

Conclusions: High quality H\&E stained sections remain the best method for establishing the diagnosis of sarcomas .Reticulin stain proved extremely helpful in subclassifying sarcomas and S100 protein was instrumental in changing the diagnosis of sarcoma in one case.
\end{abstract}

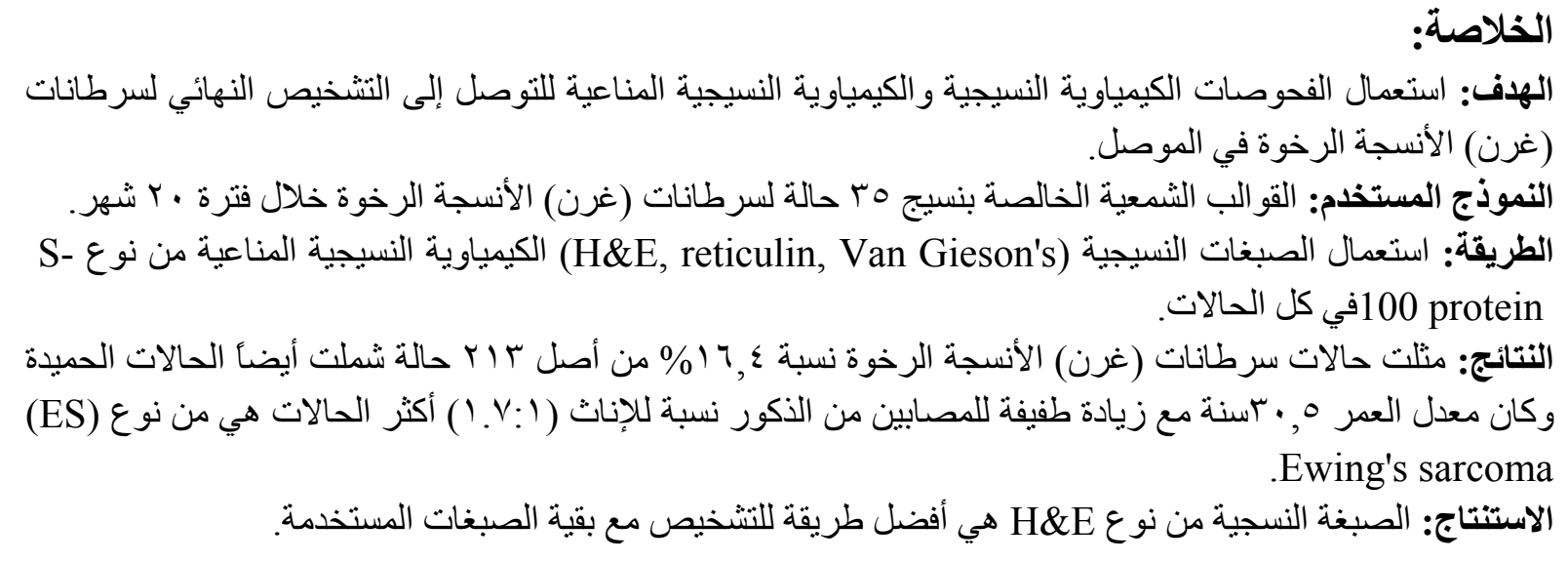


S oft tissue sarcomas (STS) are $\mathcal{S}$ heterogeneous group of malignant neoplasms which arise predominantly from the embryonic mesoderm ${ }^{(1,2)}$. They are tumors of extra skeletal connective tissues of the body, grouped together owing to similarities in clinical presentation, pathologic appearance and biologic behavior $^{(3)}$. They define a group of histologically and genetically diverse cancers that account for approximately $1 \%$ of all adult malignancies ${ }^{(3,4)}$. Sarcomas can occur any where in the body, particularly in the extremities in $29 \%$ of the cases; trunk (19\%); retroperitoneum (15\%); or the head and neck $(9 \%)^{(5)}$

The most commonly diagnosed subtypes are malignant fibrous histiocytoma; leiomyosarcoma; liposarcoma; synovial sarcoma, and malignant peripheral nerve sheath tumors (MPNST) ${ }^{(6,7)}$.

Rhabdomyosarcoma is most common in childhood $^{(6,7)}$. On the other hand, nonrhabdomyosarcomatous soft tissue sarcomas (NRSTS) account for nearly three percent of childhood malignancies ${ }^{(8)}$. Soft tissue sarcomas usually afflict old persons, with a median age of 56 years, and a male; female ratio of $1: 1^{(9)}$. Reticulin stain is of particular importance in demonstrating the reticular fibers (type III collagen) and basement membrane material (type IV). However, it is useful to depict hemangiopericytoma, vascular smooth muscle, fibrosarcoma versus endothelial cell tumors, MPNST ${ }^{(10,11)}$. Van Gieson stain is suitable to confirm fibroblastic nature of a lesion on attempting to decide whether a spindle cell tumor is a fibrosarcoma or leiomyosarcoma $^{(10,11)}$. S-100 protein is demonstrated in 50 to $90 \%$ of MPNST ${ }^{(12)}$.

The main objectives of this study are subtyping of already diagnosed sarcomas by applying reticulin stain, Van Gieson stain, and immunohistochemical marker S-100 protein, assess histologic grading by reevaluation of H\&E stained sections, as well as finding out the relative frequency of soft tissue sarcomas in Mosul, age and gender distribution.

\section{Materials and methods:}

A retrospective pathologic evaluation of 35 cases of soft tissue sarcomas, which had been diagnosed throughout a period extending from 1st January 2004 till $1^{\text {st }}$ August 2005 in Mosul city.

The following histopathological techniques were performed to each case.

1- Routine H\&E staining method was applied for subtyping, and grading of soft tissue sarcomas utilizing FFCCSG and AJCC grading schemes.

2- Special stains; Reticulin stain (Gordon and Sweets) and Van Gieson's stain were performed to outline the distribution of reticulin and collagen fibers in various subtypes ${ }^{(13,14)}$.

3-Standard avidin-biotin peroxidase complex $(A B C)$ immunohistochemical technique for the detection of S-100 protein monoclonal antibody ${ }^{(15)}$.

\section{Results:}

There were 35 cases of soft tissue sarcomas with a mean age of 30.5 years (age range 282years), and a slight male preponderance (male: female ratio of 1.7:1).

The most common histologic subtypes are extra skeletal Ewing's sarcoma (6 cases:17.2\%), Dermatofibrosarcoma protuberans DFSP ( 5 cases :14.3\%), spindle cell sarcoma (NOS) (4 cases: 11.4\%). Fibrosarcoma, malignant fibrous histiocytoma (MFH), embryonal rabdomyosarcoma, and Liposarcomas, each represents 3 cases (8.6\%). However, other subtypes (synovial sarcoma, hemangiopericytoma, Kaposi's sarcoma, neuroblastoma, and clear cell sarcoma ) accounted for $23 \%$ of all sarcomas.

Age and sex distribution within the various subtypes is outlined in table(1).

The most common primary sites are extremities $(51.4 \%)$, particularly the lower limbs; retroperitoneum and trunk (14.3\%), whereas other various locations are relatively rare (34\%), as assigned in table (2). Staining patterns:

The cartwheel growth pattern of DFSP(figures 1\&2), fibrosarcoma (figures $3 \& 4$ ) and the proliferating pericytes in hemangiopericytoma are clearly identified in H\&E, Reticulin and Van 
Gieson's stained sections, whereas the epithelial and sarcomatous elements of biphasic synovial sarcoma are readily seen in both H\&E and reticulin stained sections (figure5). Peripheral neuroblastoma has the characteristic of well circumscribed masses of small round cells in a fibrillary stroma .Kaposi's sarcoma shows fascicles of plumpy spindle cells, easily recognized by H\&E stain.Spindle cell sarcoma (NOS) case is depicting a marked nuclear hyperchromasia and intense S-100 protein immunoreactivity(figures $6 \& 7$ ). Both FFCCSG and AJCC grading systems are applied in all cases, majority of which were related to the high grade category as illustrated in table (3).

Table (1): Age and sex distribution of soft tissue sarcomas subtypes.

\begin{tabular}{|c|c|c|c|c|}
\hline Subtypes of Sarcomas & No.(\%) & Male & Female & $\begin{array}{c}\text { Mean age } \\
\text { (age range) yrs }\end{array}$ \\
\hline $\begin{array}{l}\text { ES\PNET } \\
\end{array}$ & $6(17.2)$ & 4 & 2 & $17(5-35)$ \\
\hline DFSP & $5(14.3)$ & 5 & $\mathbf{0}$ & $26(16-50)$ \\
\hline MFH & 3(8.6) & 1 & 2 & $55(50-82)$ \\
\hline Fibrosarcoma & 3(8.6) & 2 & 1 & $42(16-55)$ \\
\hline $\begin{array}{c}\text { Embryonal } \\
\text { rhabdomyosarcoma }\end{array}$ & 3(8.6) & 3 & 0 & $15(4-26)$ \\
\hline $\begin{array}{l}\text { Well differentiated } \\
\text { liposarcoma }\end{array}$ & 2(5.7) & 2 & 0 & $46(38-54)$ \\
\hline Hemangiopericytooma & 2(5.7) & 1 & 1 & $26.5(20-33)$ \\
\hline Synovial sarcoma & 2(5.7) & 2 & $\mathbf{0}$ & $28(21-35)$ \\
\hline Neuroblastoma & 2(5.7) & $\mathbf{0}$ & 2 & $9.3(2.5-16)$ \\
\hline Myxoid liposarcoma & $1(2.8)$ & $\mathbf{0}$ & 1 & 26 \\
\hline Kaposi sarcoma & $1(2.8)$ & $\mathbf{0}$ & 1 & 35 \\
\hline Clear cell sarcoma & $1(2.8)$ & $\mathbf{0}$ & 1 & 43 \\
\hline $\begin{array}{c}\begin{array}{l}\text { Spindle cell sarcoma } \\
\text { (NOS) }\end{array} \\
\text { (N) }\end{array}$ & $4(11.4)$ & 2 & 2 & $48(22-52)$ \\
\hline Total & 35(100) & 22 & 13 & $30.5(2.5-82)$ \\
\hline
\end{tabular}

Table (2): Primary sites of soft tissue sarcomas throughout the body.

\begin{tabular}{||c|c||}
\hline Site & No.( \% ) \\
\hline \hline Lower extremity & $10(28.6)$ \\
\hline Upper extremity & $\mathbf{8 ( 2 2 . 9 )}$ \\
\hline $\begin{array}{c}\text { Trunk \& } \\
\text { Retroperitoneum }\end{array}$ & $5(14.3)$ \\
\hline Miscellaneous & $12(34.3)$ \\
\hline Total & $35(100)$ \\
\hline
\end{tabular}

Table (3): FFCCSG and AJCC grading systems in various sarcomas.

\begin{tabular}{|c|c||}
\hline Grade & No. (\%) \\
\hline \hline \multicolumn{2}{|c|}{ FFCCSG System } \\
\hline Grade I & $9(25$. \\
\hline Grade II & $9(25.7)$ \\
\hline Grade III & $17(48.6)$ \\
\hline \multicolumn{2}{|c|}{ AJCC system } \\
\hline G1 & $9(25.7)$ \\
\hline G2 & $3(8.6)$ \\
\hline G3 & $9(25.7)$ \\
\hline G4 & $14(54.28)$ \\
\hline
\end{tabular}




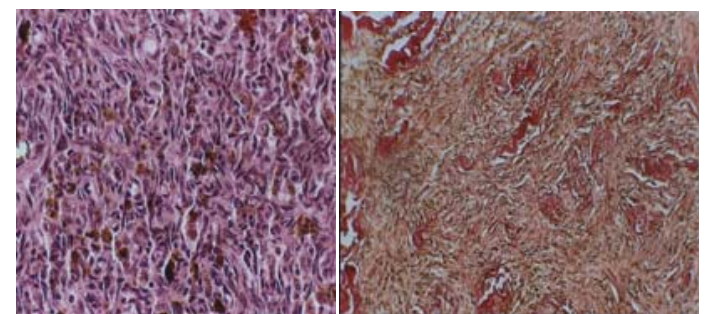

Figure(1) (left) Cartwheel growth pattern in DFSP(H \& E stain).

Figure(2)(right) Subcutaneous connective tissue surrounding DFSP is seen infiltrated by the neoplastic spindle cells(Van Gieson's stain).

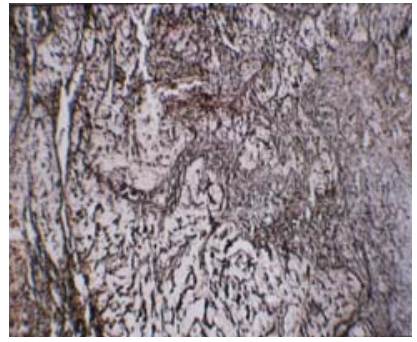

Figure(5) The epithelial nests are sharply enclosed within reticulin network in biphasic synovial sarcoma(reticulin stain).

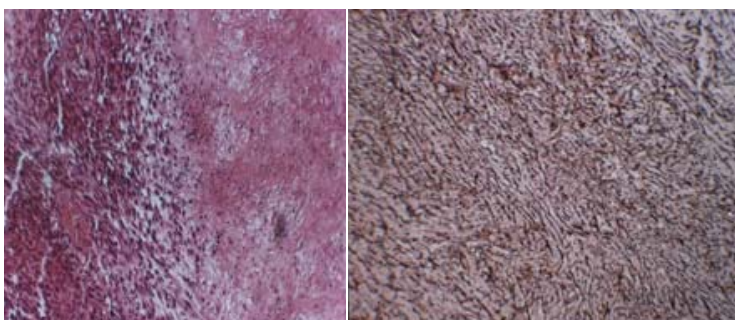

Figure(3) (left) High grade fibrosarcoma with extensive necrosis ( $\mathrm{H}$ \& E stain).

Figure(4)(right) Reticulin fibers surrounding individual cells in a well differentiated fibrosarcoma(reticulin stain).
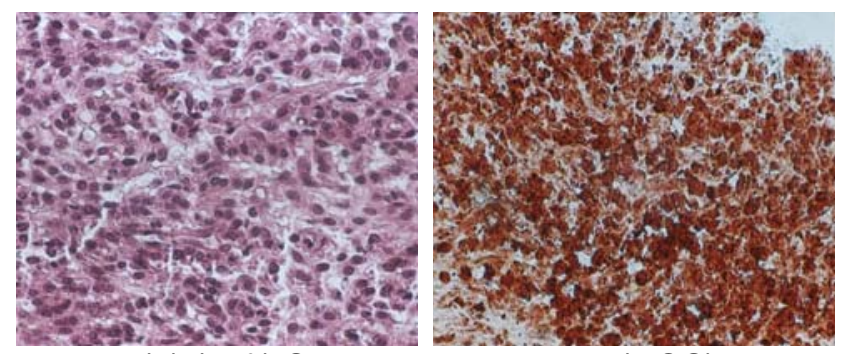

Figure(6) (Left) Spindle cell sarcoma (NOS)has a marked nuclear hyperchromasia (H \& E stain). Figure(7)(right) Intense positivity of S-100 protein in a case of spindle cell sarcoma (NOS).

\section{Discussion:}

According to standard knowledge, soft tissue sarcomas account for $1-2 \%$ of all malignant neoplasms ${ }^{(3,4,16-19)}$. However, in this study they represented $16.4 \%$ of soft tissue neoplasms [Benign: Malignant ratio of 100:18], and this is not much different from that recognized in a previous study from Mosul in $1997(21 \%$ with Benign: Malignant ratio of $100: 25)^{(20)}$. The mean age recognized $(30.5$ years) with a male: female ratio of $1.7: 1$ is relatively akin to the findings of other authors which vary between $1-3: 1^{(17,20-23)}$. The extremities are more prone to be targeted by sarcomas, in particular, the lower limbs, and this was also observed in similar studies $^{(1,6,9,17,24)}$.ES/PNET and DFSP were the most frequent soft tissue sarcomas found in our study, which was different from other surveys ${ }^{(25-28)}$.

Malignant fibrous histiocytoma was considered as the most common soft tissue sarcoma in adult life $e^{(1,6,3)}$, while liposarcoma

and leiomyosarcoma were the prevailing subtypes by others ${ }^{(17,21)}$. ES/PNET is a rare childhood malignancy which is histologically similar to skeletal $\mathrm{ES}^{(25)}$. In this study the relative frequency, the male predilection and the age incidence were close to others ${ }^{(25-27)}$ and half of the six cases encountered were recognized in the lower extremities as was documented by others ${ }^{(27)}$. These findings highlight the well known facts about these tumors as being aggressive and of high $\operatorname{grade}^{(26,27)}$.

Dermotofibrosarcoma protuberans was the second most common malignancy in this study (14.3\%), showed a tendency to affect young adults with a predilection for the upper extremities. The age of patients, the site distribution of their tumors as well as the grading status are concordant with those described by Sabine et al $2002^{(28)}$. Reticulin and Van Gieson's stains were very helpful in outlining the individual spindle cells as 
reported by others ${ }^{(10,11)}$. There was no immunoreactivty for S-100 protein, since they lack the specific Immunohistochemical markers $^{(12,28)}$.

Malignant fibrous histiocytoma is the most common subtype according to some reports ${ }^{(24,29)}$, but in the current study, it resided fourthly in order of frequency and presenting only in adults as assigned by others ${ }^{(29,30)}$. It frequently occurs in the extremities and retroperitoneum ${ }^{(29,30)}$. All the cases of MFH have predominantly the storiformpleomorphic pattern, high grade with significant foci of necrosis and ample mitotic figures, as described by Chibon et $\mathrm{al}^{(31)}$. The reticulin staining pattern simulated that of DFSP and fibrosarcoma, by outlining the individual cells and blood vessels ${ }^{(10,11)}$. Van Gieson's stain showed dispersed fine collagenous fibrils, while the tumor cells were not reactive for S-100 protein as observed by other authors ${ }^{(12,16,32)}$. Fletcher et $\mathrm{al}^{(33)}$, and Meister et $\mathrm{al}^{(34)}$ attested a retrospective evaluation of cases of MFH depending on newly defined histopathologic criteria and observed that these cases can be reclassified into other entities.

Fibrosarcoma, represents about $10 \%$ of musculoskeletal sarcomas with an age range of 35-55 years and often arising in the soft tissue of the extremities ${ }^{(35)}$. These features are similar to our findings. Two cases of fibrosarcoma are related to the high grade category, being very cellular with marked cytologic atypia, brisk mitotic activity, and evident necrosis, whereas the other case is of a low grade with morphologic resemblance to the normal fibroblasts. Reticulin fibers were observed clearly surrounding individual cells at their poles, as was described by others $^{(11,14,36,37)}$.

Embryonal rhabdomyosarcoma is the most common soft tissue sarcoma in childhood accounting for $5 \%$ of all childhood malignancies ${ }^{(38,39)}$ with male predominance ${ }^{(38)}$. In the present study it was diagnosed in three males with a mean age of 15 years, so its frequency of $8.6 \%$ (3 cases) is close to that of Hussein $^{(20)}$ in which embryonal rhabdomyosarcoma accounted for $12.5 \%$ of all sarcomas. One case showed predominance of round cell component with an intense immunoreactivity for S-100 protein, however, both ES/PNET and embryonal rhabdomyosarcoma can show this positivity ${ }^{(40,41)}$. All the cases of embryonal rhabdomyosarcoma fell within the high grade group (grade 4, G4), akin to other studies ${ }^{(42)}$.

Liposarcoma was predominantly afflicting adults (40-60 years), arising mostly in the lower extremities. These findings are similar to others $^{(43,44)}$. The single case of myxoid liposarcoma occured in an adult female in her third decade which is characteristic of this cancer as stated by Smith et $\mathrm{al}^{(45,46)}$. Likewise, $\mathrm{S}-100$ protein was negative in the three cases as noticed by others ${ }^{(12)}$. Both well differentiated and myxoid liposarcomas were low grade malignancies, an observation matching those in comparable studies ${ }^{(45,46)}$.

Hemangiopericytoma is an uncommon stromovascular neoplasm that arises from the pericytes of Zimmermann ${ }^{(47)}$. It has been described in all age groups ${ }^{(47)}$, with an equal sex distribution ${ }^{(48)}$. The retroperitoneum, extremities, head and neck are more frequently involved sites ${ }^{(47-49)}$. It was attested in two cases, a male and a female, of 20 years and 33 years respectively. Both cases were of high grade lesions with a high mitotic count $>$ 4/10 $\mathrm{HPF}^{(48)}$, marked cellularity and pleomorphism with areas of hemorrhage and necrosis.Reticulin stain was very useful in depicting the reticulin meshwork surrounding packed pericytes as described by others ${ }^{(50)}$.

Biphasic and monophasic synovial sarcomas were recognized in two cases in the present study $(5,7 \%$ of the soft tissue sarcomas ). The patients were both males of 21years and 35 years respectively with tumours in lower extremities. Similar clinical features were described by others ${ }^{(51-53)}$. In these studies, synovial sarcomas accounted for $5-20 \%$ of all malignant soft tissue neoplasms, most frequently affecting young adults with a slight male predominance, and primarily located in the extremities. Biphasic synovial sarcoma was perfectly demonstrated by reticulin stain, which outlined the well defined epithelial cell nests as well as the sarcomatous spindle cell 
component. The mechanisms involved in its epithelial differentiation are still unknown ${ }^{(54)}$. Van Gieson's stain did not have particular pattern in synovial sarcoma, and no immunoreactivity for S-100 protein was recognized, as mentioned by others ${ }^{(12,52)}$.

Neuroblastoma is the most common neoplasm during infancy ${ }^{(55)}$, being extremely rare in children older than 5 years ( with boy: girl ratio of 1.2) ${ }^{(56)}$. Peripheral neuroblastoma, on the other hand ,is a tumor of soft tissue which is morphologically similar to neuroblastoma but can occur at any age ${ }^{(19)}$. The two cases in our study occurred in females 2.5 and 16 years. both were characterized morphologically by relatively well defined nests of small round cells in a fibrillary stroma. These nests were outlined by thin fibrous bands which were intensely stained by reticulin stain. Neuroblastoma in the present study belongs to the high grade lesions (G4, undifferentiated) $)^{(55)}$. S-100 protein was negative in our and in other studies ${ }^{(12,57)}$.

Kaposi's sarcoma is appreciated as grade II (G2) malignancy according to FFCCSG and AJCC grading schemes. Its occurrence was in an adult female who was a recipient of kidney transplant. The tumor was multicenteric including the lower extremity, as observed by Papadopulose et $\mathrm{al}^{(58)}$. Histologically it is recognized as a highly angiogenic tumor characterized by aberrant proliferation of vascular structures and enhanced vascular permeability as attested by others ${ }^{(59,60,61)}$.

Spindle cell sarcomas (NOS) are also dictated by other authors ${ }^{(31,62)}$, as representing $2 \%$ of all sarcomas of the soft tissues. The case included in this study showed strong immunoreactivity for S-100 protein. Thus, the diagnosis was changed to MPNST(malignant peripheral nerve sheath tumor) rather than fibrosarcoma since the positivity for this marker can be demonstrated in $50-90 \%$ of cases $^{(46,62)}$.

\section{References:}

1. Janice N Cormier and Raphael E Pollock. Soft tissue sarcomas. CA Cancer J Clin. 2004;54:94-109.
2. Jemal A, Tiwari R C,Murray $\mathrm{T}$, et al. Cancer statistics 2004. CA Cancer J Clin 2004;54:829.

3. Ramesh C R, Roger A, Cyril F, et al.Prognostic index for extremity soft tissue sarcomas with isolated local recurrence. Annals of surgical oncology 2001; 8:278-289.

4. Neil H S,Paul P, Antonescu C R, et al. Classification and subtype prediction of adult soft tissue sarcoma by functional genomics. American Journal of Pathology 2003; 163:691700.

5. DeVita V J, Hellmann S,Rosenburg S A. Cancer: Principles and practice of oncology $.6^{\text {Th }}$ Ed.Philadelphia, PA: Lippincott Williams and Wilkins 2001;1841-1891.

6. Coindre $\mathrm{J} \mathrm{M}$, Terrier $\mathrm{P}$, Guillou $\mathrm{L}$,et al. Predictive value of grade for metastasis development in the main histolgic types of adult soft tissue sarcomas; A study of 1240 patients from the French Federation of Cancer Centers Sarcoma Group. Cancer 2001;91:1914-1926.

7. Lawrence $W, J$ r. Soft tissue sarcomas in adults and children. CA-A Cancer Journal for Clinicians 1994;44(4):197-199.

8. Spunt S L, Poquette C A, Hunt $Y$ S, et al.Prognostic factors for children and adolescents with surgically resected nonrhabdomyosarcomatous soft tissue sarcomas : An analysis of 121 patients treated at St Jude Children's Research Hospital. Journal of Oncology 1999;17:3697-3705.

9. Koea J B, Leung $D$, Lewis $J \mathrm{~J}$, et al. histopathologic type: An independent prognostic factor in primary soft tissue sarcomasof the extremite ? Annals of Surgical Oncology 2003;10:432-440.

10.Soft tissue tumors. Pathology outlines .pathologyoutlines.com ,2005(Internet).

11.John D Bancroft, and Alan Stevens. Connective tissues, chapter4.In: Histopathologic stains and their diagnostic uses .Churchill Livingstone, Edinburgh, UK 1985;35-47.

12.Eissa S, Shoman S. Tumor markers in soft tissue sarcomas. In: Tumor Markers. Champan \& Hall, London, UK 1998;377-384.

13.Lunu L G. Methods for connective tissues, chapter 4. In manualof histologic staining 
methods of the Armed Forces Institute of pathology, $3^{\text {rd }}$ ed. McGrawHill book company, New York, USA 1968;72-100.

14.Bancroft J D ,Stevens A. Connective tissues and stains, chapter 8: Theory and practice of histologic techniques, $2^{\text {nd }}$ edition. Churchill Livingstone, Edinburgh, UK 1982;142-143.

15. Eissa S, Shoman S. Tumor markers Technical aspects, part one.In: Tumor Markers. Champan and Hall, London, UK 1998;3-27.

16. Oliveira A M, Fletcher J A .CHIPing soft tissue tumors: Will the paradigms be changed ? : On: Nielson T, West R, Linn $\mathrm{S}$,et al . Molecular characterization of soft tissue tumors : a gene expression study. Lancet 2002;354:13011307.Adv Anat Pathol 2003;10(1):1-7.

17.Ray-Coquard, Thiesse P, Ranchere-Vince D, et al. Conformity to clinical practice guidelines, multidisciplinary management and outcome of treatment for soft tissue sarcomas . Annals of Oncology 2004;15:307-315.

18. Ramanathan R C, Roger A, Thomas J M. Modified staging system for extremity soft tissue sarcomas. Am J Clin Pathol 1999;6(1):57-69.

19. Enzinger F M, Weiss S W .Soft tissue tumors, $2^{\text {nd }}$ edition .Mosby, St Louis, USA 1988:p 2.

20. Hussein $H A$.Soft tissue tumors, one year survey in Mosul A thesis submitted to the Iraqi commission for medical specialization 1997;p 25.

21. Levine $E A$. Prognostic factors in soft tissue sarcoma. Semin Surg Oncol 1999;17.

22. Christopher D M, Cin P D, Wever I, et al. Correlation between clinicopathological features and karyotype in spindle cell sarcomas A report of 130 cases from the CHAMP study group. Am J Pathol 1999;154:1841-1847.

23. Keel $S$, Jaffe $K A$, Nielsen $P$, et al. Orthopaedic implant-relatd sarcoma: A study of Twelve. Mod Pathol 2001;14:969-977.

24. Marcus S G, Merino M J, Glatstein E, et al. Long term outcome in 87 patients with low grade soft tissue sarcoma. Arch Surg 1993;128(12):1336-1343.

25. Alava E ,Panizo A, Antonescu, et al. Associattion of EWS-FLI 1 type 1 fusion with lower prliferative rate in Ewing's sarcoma . Am J Pathol 2000;156:849-855.

26. Shin J H, Lee H K, Rhim H S, et al. Spinal epidural extraskeletal Ewing's sarcoma : MR findings in two cases .Am J Neuroradiology 2001;22:795-798.

27.Burchill S A. Ewing's sarcoma: Diagnostic, prognostic, and therapeutic implications of molecular abnormalities .Journal of Clinical Oncology 2003;56:96-102.

28. Sabine C L, West R B, Pollack J R, et al. gene expression pattern and gene copy number changes in dermatofibrosarcoma protuberans. Am J Pathol 2003;163:2383-2395.

29. Hirofumi $N$, Kiyoko $Y$,Joyama $S$, et al. Interleukin 6 /soluble Interleukin 6 receptor signaling attenuates proliferation and invasion, and induces morphological changes of a newly established pleomorphic MFH cell line. Am J Pathol 2004;165:480.

30.Huang C C, Ko S F, Ng S H ,et al. Cystic malignant fibrous histiocytoma of gastrocolic ligament. British Journal of Radiology 2001;74:651-653.

31.Chibon F, Mariani D, Derre J, et al. ASK 1 as a potential therapeutic targt in MFH with 12q14q15 and 6q23 amplifications, gene chromosomes .Cancer 2004;40(1):32-37.

32. Hasegawa $T$, Hasegawa $F$, Hirose $T$, et al. Expression of smooth muscle markers in so called malignant fibrous histiocytoma. Journal of Clin Pathol 2003;56:666-671

33. Fletcher C D M , Gustafson P, Rydholm A, et al .Clinical re-evaluation of 100 malignant fibrous histiocytomas: Prognostic prevalence of subclassification. J Clin Oncol 2001;19:30453050.

34. Meister P. malignant fibrous histiocytomaHistomorphological pattern of tumor type. Pathol Res Pract 1996;192:877-881.

35. Lilleng $P R$, Monge $O R$, Walloe $A$, et al. Fibrosarcoma in children - A rare tumor with long term survival even with advanced disease - A report of three cases. Acta Oncol 1997;36(4):438-440.

36. Hinarijos P, Escuder M C, Monlau J C, et al. Fibrosarcoma at the site of metallic fixation of the tibia - A case report and literature review. Acta Orthop Scand 2000;71(3):329-332. 
37.Peabody T D, Gibbs C P, Simon M A, et al. Evaluation and staging of musculoskeletal neoplasms .Am J Dermatopath 1998;20(1):89102.

38. Alberto $S \mathrm{P}$, James $\mathrm{R} \mathrm{A}$, William M C, et al. Survival after relapse in children and adolescents with rhabdomyosarcoma: A Report from the Intergroup Rhabdomyosarcoma Study Group. Journal of Clin Oncol 1999;17(11):3487-3493.

39. Marco W, Marcel D, Eva K, et al. Gene expression signatures identify rhabdomyosarcoma subtypes and detect a novel $t(2: 2)(q 35: p 23)$ translocation fusing PAX 3 to NCOA 1. Cancer Res 2004;64:5539-5545.

40. Hamilton G, Havel M. Ewing's sarcoma associated HBA-71 tumor antigen represents a new differentiation marker of human thymocyte. J Res Clin Oncol 1989;115:595596.

41.Coindre J M, DeMascarel A, Trojani M, et al. Immunohistochemical study of rhabdomyosarcoma : unexpected staining with S-100 protein and cytokeratin .J Pathol 1988;155:127.

42.Shiraki M, Enterline H T, Brooks $\mathrm{J} J$,et al. Pathologic analysis of advanced soft tissue sarcomas, bone sarcomas and mesotheliomas. The Eastern Cooperative Oncology Group (ECOG) experience .Cancer 1989;64:484-490.

43. Weiss S W, Rao V K. Well differentiated liposarcoma of deep soft tissue of the extremities, retroperitoneum, and miscellaneous sites. A follow up study of 92 cases with analysis of the incidence of "dedifferentiation" .Am J Surg Pathol 1992;16:1051-1058.

44. Mentzel T. Lipomatous tumors of the skin and soft tissue. New entities and concepts .Pathologe 2000;21(6):441-448.

45.Smith T A. Myxoid/round cell liposarcoma of the extremities. A Clinicopathological study of 29 cases with particular attention to extent of round cell liposarcoma. Am J Surg Pathol 1996;20:171-180.

46. Allen P W, Strungs I, MacCormac L B. Atypical subcutaneous fatty tumors: a review of 37 referred cases. Pathology 1998;30(2):123-135.

47.Buscema J, Rosenshein N B, Taqi F, et al. Vaginal hemangiopericytoma: histopathologic and ultrastructural evaluation. Obstetrics and Gynecology 1985;66:582-585.

48.James G R, Philip C G. Late pulmonary metastasis from hemangiopericytoma of the mandible, unusual findings on CT and MR imaging. A J R 2001;177:144-245.

49.Argyropolou P I, Sivridis E, Giatromano L, et al. Malignant hemangiopericytoma of the knee joint: MR findings. British $\mathrm{J}$ Radiol 2002; 75:539-542.

50.Joan C V, Joaquim B, James $G S$, et al. Hemangioma from head to toe: MR imaging with pathologic correlation. Radiographics 2004;24:367-385.

51.Susanne V A, Peter B I, Chen Y, et al. Expression profiling of synovial sarcoma by $C$ DNA microarrays. Am J Pathol 2002;161:1587-1595.

52.Spillane A J, Hern R A, Judson I R, et al. Synovial sarcoma: A clinicopathologic, staging, and prognostic assessment. J Clin Oncol 2000;18(22):3794-3803.

53.Yakushiji T, Yonemora K, Tsuruta J, et al. Capacity for epithelial differentiation in synovial sarcoma : Analysis of a new human cell line . J Clin Pathol 2000;53:525-531.

54.Saito T, Oda Y, Sugimashi K, et al. E cadherin gene mutation frequently occur in synovial sarcoma as a determinant of histologic features. Am J Pathol 2001;159:2117-2124.

55.Johnson J I, Lindskog $M$, Ponthan $F$, et al. Cyclooxygenase 2 is expressed in neuroblastoma and non-steroidal antiinflammatory drugs induce apoptosis and inhibit tumor growth in vivo. Cancer Res 2004;64:7210-7215.

56. Stella M, Ross J A. Screening for neuroblastoma: Progress and pitfalls. Cancer Epidemiology Biomarkers and Prevention 1999;8:189-194.

57. Maris J M, Matthay K K . Molecular biology of neuroblastoma . J Clin Oncol 1999;17:2264.

58.Papadopulos E E, Turner V F, and Papademitriuo J M. Kaposi sarcoma and HIV. Medical Hypotheses 1992;39:22-29.

59. Montaner S, Sodhi A, Joan M S, et al. The small GTPase Rac 1 links the Kaposi sarcoma - associated herpes virus and GPCR 
to cytokine secretion and paracrine neoplasia. Blood 2004;104(9):2903-2911.

60. Ryan P, Aarons S, Murrayn D, et al. Human herpesvirus 8 (HHV-8) detected in two patients with a Kaposi sarcoma -like pyogenic granuloma. Journal of Clinical Pathology 2002;55:619-622.

61.Brown L F, Bruce J D, Tognazzi K, et al. Expression of Tie 1, Tie 2, and angiopoietins
1,2, and 4 in Kaposi sarcoma and cutaneous angiosarcoma. Am J Pathol 2000;156:21792183.

62.Schaefer K L, Brachwitz K, Wai D H, et al. Expression profiling of $\mathrm{t}(12: 22)$ positive clear cell sarcoma of soft tissue cell lines reveals characteristic upregulation of potential new marker genes including ERBB3. Cancer Res 2004;64:3395-3405. 